\title{
Deducing ballast water sources in ships arriving in New Zealand from southeastern Australia
}

\author{
Kathleen R. Murphy ${ }^{1,2, *}$, Jennifer R. Boehme ${ }^{1}$, Monaca Noble ${ }^{1}$, George Smith ${ }^{1}$, \\ Gregory M. Ruiz ${ }^{1}$
}

\author{
${ }^{1}$ Smithsonian Environmental Research Center, PO Box 28, Edgewater, Maryland 21037, USA \\ ${ }^{2}$ UNSW Water Research Centre, School of Civil and Environmental Engineering, The University of New South Wales, \\ Sydney, New South Wales 2052, Australia
}

\begin{abstract}
The transfer of organisms in ballast water of commercial ships is a leading cause of biological invasions in coastal ecosystems. Ships arriving in New Zealand are now required to treat their ballast water to reduce the risk of transferring invasive aquatic organisms between ports. Most of these ships conduct mid-ocean ballast water exchange (BWE), replacing coastal water with open ocean water, but methods to verify BWE have been lacking. Samples were collected from ballast tanks and the ambient ocean on ships trading between southeastern Australia and New Zealand, to test the use of chemical (chromophoric dissolved organic matter or CDOM, Ba, Mn and P) concentrations to discriminate ballast water sources. Australian ballast water provides a difficult and valuable test case for BWE verification due to its high salinity and low chemical tracer concentrations resulting from Australia's low rainfall and nutrient-poor soils. Our results indicate that elevated CDOM, Ba and Mn were robust tracers of port waters, whereas elevated P was not a diagnostic tracer except of ballast water originating from Port Phillip Bay. Exchanged ballast tanks were diagnosed by CDOM fluorescence below 2.1 (for wavelength pair $\mathrm{C} 2{ }^{*}, \mathrm{Ex} / \mathrm{Em}=320 / 414 \mathrm{~nm}$ ) and 1.2 (for wavelength pair $\mathrm{C}^{*}{ }^{*}, \mathrm{Ex} / \mathrm{Em}=370 / 494 \mathrm{~nm}$ ) (quinine sulfate equivalents, QSE), and Ba and Mn concentrations below 5.7 and $3.5 \mathrm{\mu g} \mathrm{l}^{-1}$ respectively. These results are consistent with recent studies in the northern hemisphere, indicating that elevated concentrations of these tracers are robust indicators of unexchanged ballast water. Whereas clear differences existed between port and oceanic signatures, coastal and oceanic samples could not always be distinguished due to precipitously declining tracer concentrations within short distances from land.
\end{abstract}

KEY WORDS: Ballast water exchange · Tracers · Fluorescence · Trace elements · Shipping · Verification · Aquatic invasive species Resale or republication not permitted without written consent of the publisher

\section{INTRODUCTION}

In recent years, legislative measures have increasingly been employed to mitigate the risks of environmental impacts associated with the discharge of ship ballast water (Firestone \& Corbett 2005). In New Zealand, the Biosecurity Act (1993) and the Hazardous Substances and New Organisms Act (HSNO 1996) are directed toward the prevention and management of introduced species. Of particular concern in marine environments are invasive aquatic species residing in foreign ports that have the potential to be transported to and released in New Zealand by routine commercial shipping activities (Cariton \& Geller 1993, Hewitt et al. 2004b, MAF 2007). Worldwide, invasions by non-native species are considered to be a major threat to native biological diversity (Pimentel et al. 1997), while a small number of invasive aquatic species are blamed for economic damages totaling billions of dollars per year (Knowler 2005, Pimentel et al. 2005, Stokstad 2007).

Nearly 3 million tons of foreign ballast water are discharged in NZ territorial waters each year (MAF 2007). Any associated invasions can pose a direct threat to the nation's prosperous fisheries and aquaculture industries, valued at NZ $\$ 3.97$ billion (US $\$ 2.7$ billion) in 2008 (Statistics New Zealand 2009), and may also 
cause losses in biodiversity that are often difficult to quantify (Pimentel et al. 1997, Patterson \& Cole 1999). Current regulations specify that all ships must seek advance permission to discharge ballast water in New Zealand territorial waters, and that no coastal ballast water may be discharged unless it has first been treated using mid-ocean ballast water exchange (BWE) or an approved alternative technology, or unless an exemption has been granted on the basis of crew safety or vessel construction (MAF 2005). An annex to this standard removes the right to an exemption from ships carrying ballast water from locations in Australia considered to be of particular threat to New Zealand (Port Phillip Bay in Victoria, Hewitt et al. $2004 \mathrm{a}$; and all coastal waters of Tasmania). Located 1000 nautical miles (nmi) west across the Tasman Sea, Australia is New Zealand's largest single trading partner, accounting for $\sim 66 \%$ of New Zealand's total imports and exports totaling over $\$ 18$ billion $\mathrm{yr}^{-1}$ (Statistics New Zealand 2002). In 2005-2006, there were 917 ship arrivals recorded from Australia involving the discharge of over 700000 tons of ballast water, 22\% of which originated from Port Phillip Bay (MAF Biosecurity New Zealand Ballast Water Database unpubl. data). Ballast water from Port Phillip Bay is of particular concern to New Zealand due to the presence in the bay of 5 marine pest species named on the New Zealand Register of Unwanted Organisms under the 1993 Biosecurity Act.

When conducting BWE, the vessel replaces its 'highrisk' coastal ballast water with 'low-risk' ballast water collected from the open ocean while traveling enroute to New Zealand. This process interrupts the port-toport transfer of coastal organisms by compromising or removing propagules of invasive species (IMO 2004, Minton et al. 2005, Santagata et al. 2008). Overseas experience has shown that although many ships attempt to conform with BWE legislative requirements (Miller et al. 2004, 2008), relying on ships' statements and records for confirmation that BWE was conducted appropriately (i.e. with at least $95 \%$ exchange efficiency at sufficient distances from land) is problematic (Cohen \& Foster 2000, Firestone \& Corbett 2005). Recent research efforts have focused on inferring ballast water origin from its chemical signature, by comparing the chemical profile of ship ballast water with that of water from ports, coasts and oceanic environments (Murphy et al. 2004). Research in the Pacific and Atlantic oceans suggests that knowledge of the concentrations of chromophoric dissolved organic matter $(\mathrm{CDOM})$ and/or certain trace elements (barium, manganese and phosphorus) in ballast water can assist in deducing whether a ballast tank has been exchanged in mid-ocean (Murphy et al. 2006, Hunt et al. 2007, Murphy et al. 2008b).
Dissolved organic matter is produced by the breakdown of terrestrial and aquatic plant matter to humic, fulvic and amino acids and is found in all natural waters. The term CDOM refers to the optically active (chromophoric) fraction of the dissolved organic matter pool that absorbs light in the blue and UV regions of the spectrum, a fraction of which emits UV and visible light (fluoresces) with an intensity proportional to the amount of material present (Blough \& Del Vecchio 2002). Several studies have documented much greater CDOM fluorescence in coastal waters near terrestrial sources than in the open ocean where CDOM is removed by light and biogeochemical processes (Blough et al. 1993, Mopper \& Schultz 1993, Moran et al. 2000, Chen et al. 2002, Murphy et al. 2008c). In ships operating in the North Atlantic and Pacific Oceans, Murphy et al. (2006) identified fluorescence 'compliance thresholds' of 1.7 and 0.7 quinine sulfate equivalents (QSE)) at wavelength pairs C2* (Excitation/Emission wave lengths $(E x / E m)=320 / 414 \mathrm{~nm})$ and $C 3^{*}(\mathrm{Ex} / \mathrm{Em}$ $=370 / 494 \mathrm{~nm}$ ) that successfully discriminated coastal from oceanic sources in the majority of ballast tanks sampled. While concentrations of $\mathrm{C} 2{ }^{*}$ and $\mathrm{C} 3^{*}$ are typically highly correlated in coastal waters, they appear to have fundamentally different sources, with $\mathrm{C} 2{ }^{*}$ representing new microbially produced fulvic-like organic matter and $\mathrm{C} 3^{*}$ representing old, refractory terrestrial material (Murphy et al. 2008c).

$\mathrm{Ba}, \mathrm{Mn}$ and $\mathrm{P}$ concentrations are typically elevated in coastal waters relative to the open oceans due to terrestrial and anthropogenic inputs from land. Although the relationship is geographically variable and dependent upon a range of factors including rainfall and biochemistry, their concentrations in coastal waters are typically elevated above background oceanic levels by a factor $\geq 2$ for dissolved Ba (Hanor \& Chan 1977, Shaw et al. 1998), $\geq 20$ for dissolved Mn (Bruland \& Franks 1983, Shiller 1997, Wells et al. 2000), and $\geq 10$ for total dissolved P (Froelich et al. 1982, Baturin 2003). Previous studies have shown that CDOM and $\mathrm{Ba}, \mathrm{Mn}$ and $\mathrm{P}$ can be measured reliably in ship ballast water and can be sensitive discriminators of high-salinity coastal versus oceanic ballast water, even when salinity differentials and other terrestrial influences are small (Murphy et al. 2008b).

The application of these tracers for BWE verification has been demonstrated in the North Pacific and Atlantic oceans, but their distribution and potential use for discriminating ballast water sources in the southern hemisphere is largely unknown. Importantly, Australian ballast water provides an especially challenging and valuable test case for BWE verification due to its high salinity and low chemical tracer concentrations resulting from Australia's low rainfall and nutrientpoor soils. In the present study, salinity, $\mathrm{CDOM}, \mathrm{Ba}$, 
Mn and $\mathrm{P}$ were measured in the ballast water of ships trading between southeast Australia (Geelong, Botany Bay, Bell Bay and Port Adelaide) and Bluff in southwest New Zealand, Bluff being a port considered to be at high risk of biological invasion (Inglis 2001, Inglis et al. 2007). Our aim was to examine (1) the chemicals' suitability for tracing ballast waters of particular concern to New Zealand and (2) whether results are similar with those in the northern hemisphere, suggesting a robust method.

\section{MATERIALS AND METHODS}

Experimental and sampling design. Four research cruises were conducted on commercial trading ships in successive quarters from 2005-2006, completing an entire seasonal year. At the start of each cruise, each vessel had multiple ballast tanks loaded with ballast water from its departure point (Geelong, Victoria or Adelaide, South Australia) or a recent port of call (Portland, Victoria or Townsville, Queensland) (Table 1). Thereafter, the ships headed along a standard route to Bluff in New Zealand, with or without intermediate stops in Portland or Bell Bay, Tasmania, except during the first cruise, when the vessel was routed through Botany Bay, New South Wales. BWE was performed enroute to New Zealand in the Tasman Sea by the empty-refill (ER) or flow-through (FT) method. Two different ships hosted the cruises, but both followed nearly identical tracks between Adelaide and New Zealand. Fig. 1 shows the locations of these ports, except for Townsville which lies on the coast of Australia, $1600 \mathrm{~km}$ northwest of Sydney.

On each cruise, seawater samples were collected from the port side (p), starboard side (s), aft peak (AP) or forward peak (FP) ballast tanks and from the ambient ocean at shipside along the cruise track (Table 1). Ballast water sampling was distributed throughout the cruise corresponding to initial ballast conditions, mid cruise, after BWE, and at the cruise end, with samples being collected at minimum from multiple pairs of ballast tanks before and after BWE, except for 2 tanks on cruise NZ2 which were sampled before BWE only. In general, 2 replicate samples of each type were collected at 2 depths in each ballast tank on each sampling occasion. Repli-

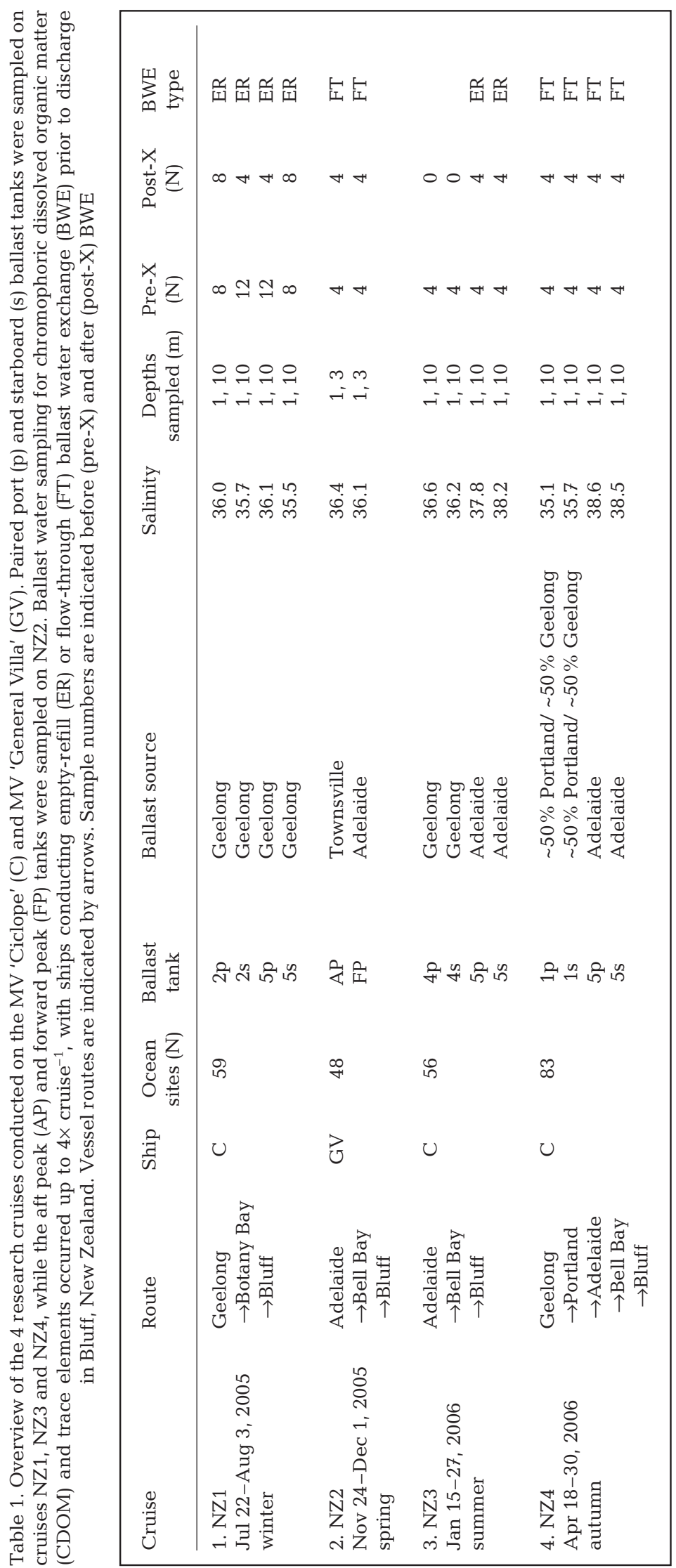




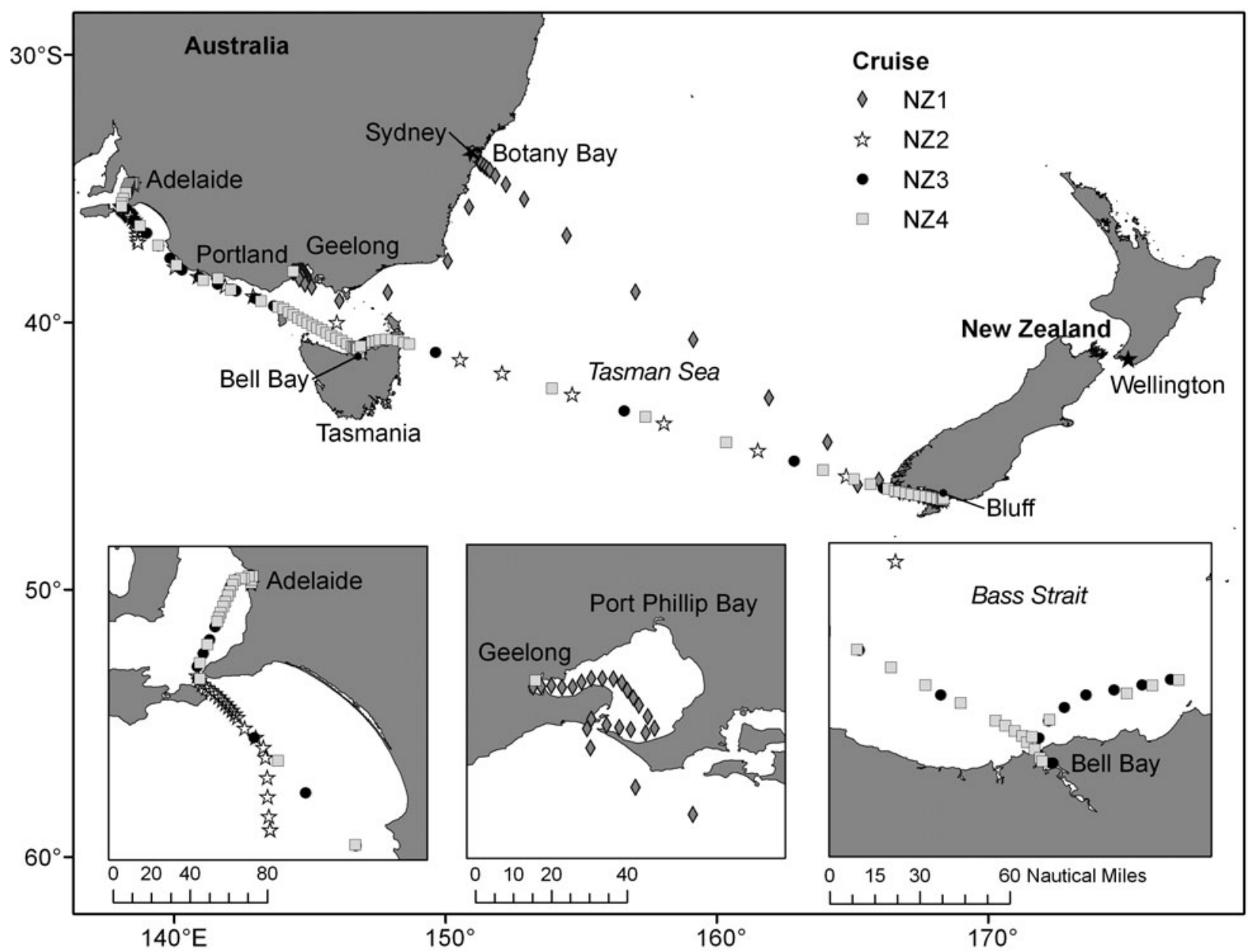

Fig. 1. Cruise tracks followed from Australia to New Zealand during the present study. Symbols show sites where seawater ambient chromophoric dissolved organic matter (CDOM) and trace element samples were collected from the ocean

cate samples $(\mathrm{n}=2)$ were also collected from each ocean site, at 5 to $10 \mathrm{~m}$ depth. Overall, a large set of ambient seawater (shipside) samples were collected and analyzed for CDOM ( $\mathrm{n}=478$ samples) and trace elements $(\mathrm{n}=485)$, and a smaller set from ballast tanks for $\operatorname{CDOM}(\mathrm{n}=135)$ and trace elements $(\mathrm{n}=133)$.

Ballast water samples were collected via acidcleaned plastic pumps (Wilden: Pro-Flo P.025) and tubing (Cole-Parmer: Chemfluor 367). Shipside samples were collected in the engine room via the seachest through which clean ambient seawater was continuously directed into pipes that circulate past the engine to cool it. In situ filtration was performed during collection via high-capacity inline polypropylene capsule filters (Osmonics, Memtrex)

Cross-contamination between samples was controlled by flushing equipment before and between sample collection, using separate filters for ballast versus seawater samples, replacing filters regularly and refrigerating them when not in use. These methods have been tested extensively and determined to be reliable for sampling our tracers of interest (Murphy et al. 2006, 2008a,b). Samples were stored in acidcleaned polypropylene centrifuge tubes (trace elements) or ashed amber glass bottles (CDOM), frozen at $-20^{\circ} \mathrm{C}$, and shipped to the laboratory at the end of each cruise.

Salinity measurements were obtained using a conductivity meter (YSI-85) that was precalibrated with distilled water and NIST-traceable seawater conductivity standard (YSI 3169, $50000 \mu \mathrm{S} \mathrm{cm}^{-1}$ ). Despite calibrations, salinity measurements on 2 cruises (NZ1 and NZ4) appeared anomalously high, thus salinities were cross-checked against comparable data sources, including WOCE 2005 records for the Tasman Sea, and hourly monitoring data for Port Phillip Bay (Longmore 2007). As a result of cross-checking, it was determined that raw salinity measurements for surveys NZ1 and NZ4 should be decreased by $2(\sim 6 \%)$, with NZ2 and NZ3 remaining unadjusted. The corrected data are 
considered to have an accuracy of \pm 1 ( $3 \%)$, which is considerably less than the precision of the sampling apparatus $( \pm 0.05)$, but comparable to that of the other tracers examined. Experimental error arising from this adjustment is expected to affect between-survey salinity comparisons to a greater extent than within-survey comparisons.

Distance from shore was calculated from the distance between the GPS position of sampling and the nearest land location (mean location at mean tide). Since the vessels typically traveled at between 3 and 20 knots while sampling took place (i.e. slowest in port and fastest on the open sea) and sampling times were recorded only within $\sim 5 \mathrm{~min}$, the error associated with shipside station positional measurements is $\sim 0.25$ to $1.6 \mathrm{nmi}$.

Sample analyses. The concentrations of $\mathrm{Ba}, \mathrm{Mn}$, and $\mathrm{P}$ were analyzed on an Element-1 high resolution inductively coupled plasma mass spectrometer (ThermoFinnigan) at Rutgers Inorganic Analytical Laboratory, Institute of Marine and Coastal Sciences (Rutgers, the State University of New Jersey). First, samples were acidified to a $\mathrm{pH}$ of $<2$ by the addition of $2 \mathrm{ml} \mathrm{l}^{-1}$ 12 M HNO3 (Optima grade, Fisher Scientific) upon thawing, then samples were diluted 10-fold with $10 \%$ v/v ultra-pure $\mathrm{HNO}_{3}$ and analyzed in low and medium resolution using published techniques (Field et al. 2007).

CDOM samples were analyzed at 2 participating laboratories. Analyses for cruise NZ1 were performed at the University of Maine using a SPEX FluoroMax-2 (from JY-SPEX), over an excitation range of 220 to $455 \mathrm{~nm}$ in $5 \mathrm{~nm}$ increments and an emission range of 290 to $600 \mathrm{~nm}$ collected every $2 \mathrm{~nm}$. Samples from cruises NZ2 to 4 were analyzed at the Smithsonian Environmental Research Center in Edgewater, Maryland using a Spex Fluorolog-3 (JY Horiba) with an experimental wavelength range of 220 to $455 \mathrm{~nm}$ in $5 \mathrm{~nm}$ intervals on excitation and 290 to 700 nanometers (nm) in $4 \mathrm{~nm}$ intervals on emission. All samples were analyzed in a $1 \mathrm{~cm}$ quartz cell maintained at $20^{\circ} \mathrm{C}$ with a temperature-controlled cell holder, and processed in ratio mode with a $0.5 \mathrm{~s}$ integration time and a $5 \mathrm{~nm}$ bandwidth for both excitation and emission. Additionally, triplicate CDOM absorbance scans were done for most samples using a $5 \mathrm{~cm}$ quartz cuvette in a UV-visible spectrophotometer (Cary $4 \mathrm{E}$ ) at $1 \mathrm{~nm}$ wavelength intervals from 290 to $750 \mathrm{~nm}$, with ultrapure water as reference.

Fluorescence excitation-emission matrices (EEMs) from both fluorometer systems were corrected for instrument and lamp variability and normalized to ppb QSE as previously described (Coble et al. 1993, method 1). Fluorescence measurements made on highly absorbing CDOM samples can be affected by inner-filter effects (IFE) caused by the attenuation of excited and/or emitted light by the sample matrix. This results in a decrease in the linear response between absorbed and emitted light and would ultimately lead to fluorescence intensities of highly absorbing samples being underestimated. IFE correction factors calculated from the absorbance measurements according to the method of Lakowicz (1983) were applied to the data. IFE correction factors were always $<3 \%$ for $\mathrm{C} 3 *$ and $<6 \%$ for $\mathrm{C} 2{ }^{*}$. For $\mathrm{C} 2{ }^{*}$, they increased approximately linearly with fluorescence intensity $\left(\mathrm{R}^{2} \sim 0.85\right)$, reaching $5 \%$ at $\sim 17 \mathrm{ppb}$. From this relationship, IFE correction factors could be estimated from fluorescence in the minority of samples that did not have corresponding absorbance measurements, with little loss of sensitivity.

Data manipulation and statistics. Prior to statistical analysis, the dataset was examined for outliers due to the sampling or analytical process. Outliers were removed from the dataset only when there was convincing evidence of their unreliability. There were no outliers detected in the ballast water dataset. In the shipside dataset, 2 types of errors were observed and affected data excluded: (1) disagreement (coefficient of variation $\mathrm{CV}>10 \%$ ) between intensities and spectra of independent replicate samples, which was caused by the contamination of one replicate ( $\mathrm{N}=1$ of 479 replicates), and (2) unexpectedly high fluorescence in both replicates collected from some sampling sites located far from known oceanic sources ( $N=5$ of 245 sites). In the first case, the contaminated replicate was easily identified. The second type of outlier occurred only on the MV 'Ciclope' at a time when the ship was undertaking BWE. It was clear from the intensities and spectral characteristics of the outlier samples that these sites had become contaminated with coastal water that originated within the ballast tanks. Finally, Ba measurements for a small number of trace element samples $(\mathrm{N}=5)$ were subject to random analytical errors and were replaced with missing values.

Exchange efficiency. BWE efficiency was estimated for each individual tank and tracer in order to assess whether (1) $95 \%$ replacement of coastal seawater had in fact occurred, and (2) different chemical tracers produced consistent estimates of BWE effectiveness. Efficiency was determined from mean concentrations measured in tanks and in the ocean at the geographically closest sites sampled before or after completion of BWE. Oceanic sites sampled during BWE were not used for this calculation since, as described previously, these were found to be contaminated with ballast water.

Assuming that chemical tracers behave conservatively during BWE and can be precisely and accurately measured in ballast tanks and in the ambient ocean, then BWE efficiency can be calculated as: 


$$
\text { BWEefficiency }=\frac{C_{\mathrm{f}}-C_{\mathrm{i}}}{C_{\mathrm{a}}-C_{\mathrm{i}}} \times 100 \%
$$

where $C_{\mathrm{i}}$ and $C_{\mathrm{f}}$ are the tracer concentrations in the ballast water before and after BWE respectively, and $C_{\mathrm{a}}$ is the tracer concentration in the ambient ocean where BWE took place.

Multivariate analysis. Partial least squares (PLS) regression was used to investigate whether coastal and oceanic seawater discrimination would be enhanced under a multivariate analysis of tracer concentrations. PLS locates an optimal set of latent vectors that decompose a matrix $\mathrm{X}$ while explaining as much of the covariance between $\mathrm{X}$ and a vector $\mathrm{Y}$ as possible (De Jong 1993). In this application, we attempted to predict distance to shore (vector $\mathrm{Y}$ ) from the log-transformed concentrations of $\mathrm{Ba}, \mathrm{P}, \mathrm{Mn}$, salinity, $\mathrm{C} 2{ }^{*}$ and $\mathrm{C} 3{ }^{*}$ (matrix X). Data were autoscaled, then modeling was performed using the SIMPLS algorithm in the PLS toolbox of Matlab (Eigenvector Research). Crossvalidation was performed via the leave-one-out (jackknifing) method.

\section{RESULTS}

\section{Effect of BWE}

\section{Salinity}

Salinity ranged from 35.1 to 38.6 psu in tanks containing unexchanged ballast water from Australian ports during this study (Table 2). Following BWE in the Tasman Sea, salinities ranged between 34.6 and 35.7, thus overlapping with salinities in unexchanged bal-

Table 2. Salinity in ballast tanks and the effect of ballast water exchange (BWE). See Table 1 for abbreviations

\begin{tabular}{lccr|}
$\begin{array}{l}\text { Cruise. } \\
\text { Tank }\end{array}$ & $\begin{array}{r}\text { Salinity } \\
\text { (initial) }\end{array}$ & \multicolumn{2}{c|}{$\begin{array}{r}\text { F Change after BWE } \\
\text { FR }\end{array}$} \\
\hline $1.2 \mathrm{p}$ & 36.0 & -0.8 & \\
$1.2 \mathrm{~s}$ & 36.7 & -0.9 & \\
$1.5 \mathrm{p}$ & 36.1 & -2.2 & \\
$1.5 \mathrm{~s}$ & 35.5 & 0.3 & -4.0 \\
$2 . \mathrm{AP}$ & 36.4 & & -3.7 \\
$2 . \mathrm{FP}$ & 36.1 & & \\
$3.4 \mathrm{p}$ & 36.6 & (no data) & \\
$3.4 \mathrm{~s}$ & 36.2 & (no data) & \\
$3.5 \mathrm{p}$ & 37.8 & -7.7 & 0.2 \\
$3.5 \mathrm{~s}$ & 38.3 & -8.8 & -1.4 \\
$4.1 \mathrm{p}$ & 35.1 & & -9.6 \\
$4.1 \mathrm{~s}$ & 35.7 & & -9.0 \\
$4.5 \mathrm{p}$ & 38.6 & & \\
$4.5 \mathrm{~s}$ & 38.5 & & \\
\hline
\end{tabular}

last tanks. In more than half of the ballast tanks sampled, the change in depth-averaged salinity as a result of BWE was $<5 \%$, and in the remainder, salinities changed by $<10 \%$ following BWE.

\section{Dissolved organic matter fluorescence}

No significant differences in CDOM concentrations were observed at different tank depths, therefore data are presented as whole-tank averages. CDOM concentrations in unexchanged ballast tanks ranged between 5 and 18.6 QSE at C2* and 2.6 and 10.6 QSE at C3*, with the highest concentrations being measured in tanks sourced from Adelaide in summer (NZ3) and the lowest being in autumn in a tank containing a mixture of ballast water from Portland and Geelong (NZ4). On all cruises, CDOM concentrations decreased significantly in all tanks as a result of BWE (Fig. 2). The change in mean CDOM concentrations due to BWE was almost identical for $\mathrm{C} 2{ }^{*}$ and $\mathrm{C} 3{ }^{*}$, averaging an $89.5 \%$ decrease for tanks exchanged by the ER method and an $86.5 \%$ decrease for tanks exchanged

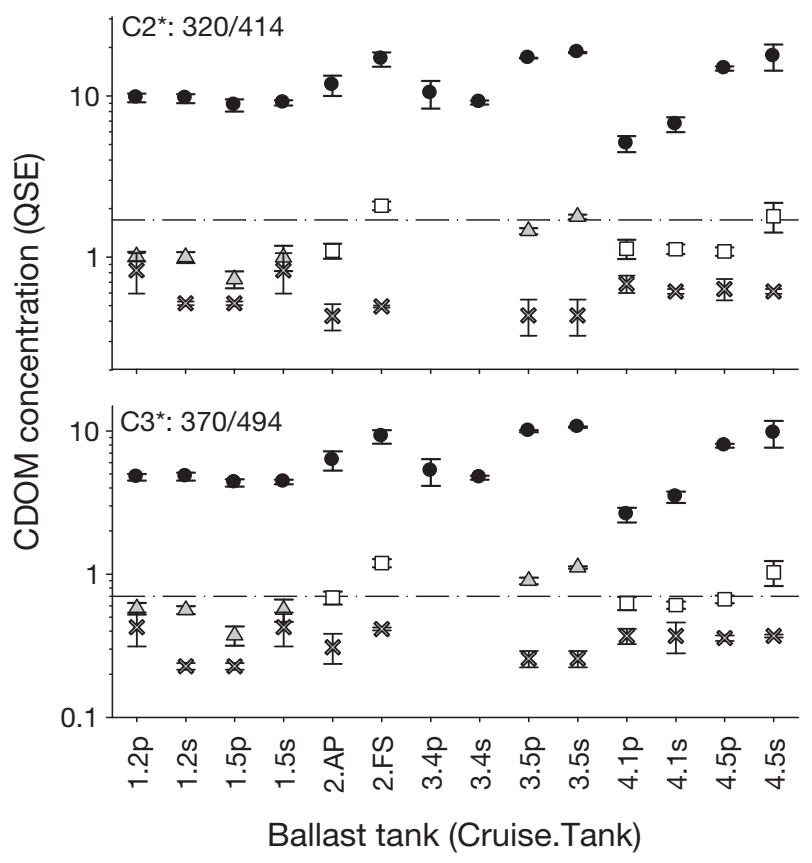

Fig. 2. Chromophoric dissolved organic matter (CDOM) concentrations at wavelengths $\mathrm{C} 2{ }^{*}(\mathrm{Ex} / \mathrm{Em}=320 / 414 \mathrm{~nm})$ and $\mathrm{C}^{*}(\mathrm{Ex} / \mathrm{Em}=370 / 494 \mathrm{~nm})$ in ballast water and in the ocean during 4 cruises across the Tasman Sea. Concentrations in quinine sulfate equivalents (QSE, mean \pm SD for true replicate samples) are shown before BWE $(\bullet)$, after BWE was performed by the ER method $(\Delta)$, after BWE was performed by the FT method $(\square)$, and in the ambient open ocean $(\boldsymbol{x})$ in the region of BWE. Ballast from tanks 3.4p and 3.4s were released in Australian waters without undergoing BWE. (-.--) BWE compliance thresholds of 1.7 for $\mathrm{C} 2{ }^{*}$ and 0.7 for $\mathrm{C} 3^{*}$ (Murphy et al. 2006). See Table 1 for abbreviations 
by the FT method. Concentrations of CDOM measured in ballast tanks after BWE were below 2.1 QSE at C2* and 1.2 QSE at C3*.

\section{Trace elements}

As in CDOM, no significant differences in trace element concentrations were observed at different tank depths and data are presented as whole-tank averages $( \pm \mathrm{SD})$. Trace element concentrations decreased following BWE in nearly all tanks on all cruises (Fig. 3). Ba

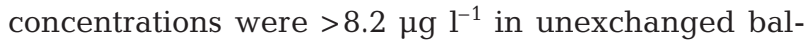
last tanks, and $<5.6 \mu \mathrm{g} \mathrm{l}^{-1}$ in tanks that had been exchanged in mid-ocean, where concentrations averaged $4.7 \pm 0.8 \mu \mathrm{g} \mathrm{l}^{-1}$. Mn concentrations were $>5.7 \mu \mathrm{g}$

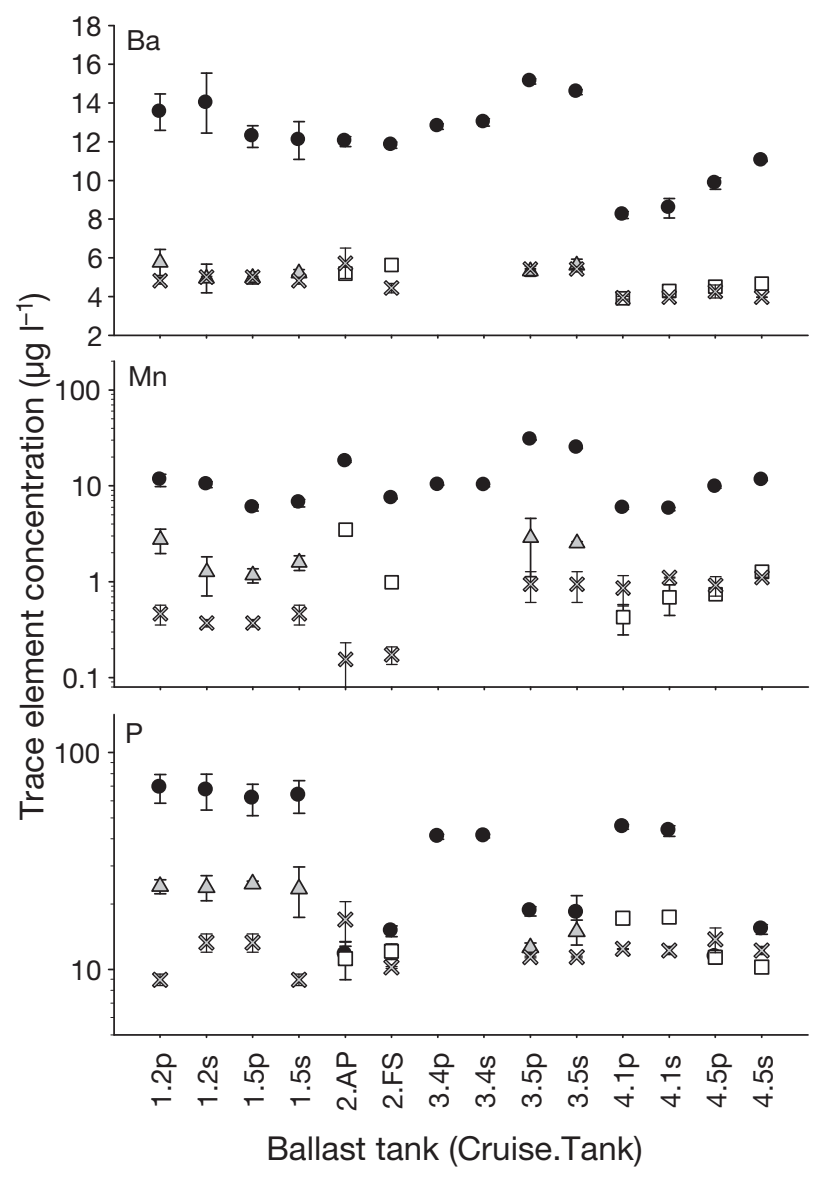

Fig. 3. Trace element concentrations in ballast water and in the ocean during 4 cruises across the Tasman Sea. Concentrations $\left(\mu \mathrm{g} \mathrm{l}^{-1}\right.$, mean $\pm \mathrm{SD}$ for true replicate samples) are shown before BWE (O), after BWE was performed by the ER method $(\Delta)$, after BWE was performed by the FT method ( $\square$ ), and in the ambient open ocean $(\boldsymbol{x})$ in the region of BWE. Ballast from tanks $3.4 \mathrm{p}$ and $3.4 \mathrm{~s}$ were released in Australian waters without undergoing BWE. See Table 1 for abbreviations $\mathrm{l}^{-1}$ in unexchanged ballast tanks, and $<3.5 \mu \mathrm{g} \mathrm{l}^{-1}$ in exchanged tanks, compared to average ocean concentrations of $0.5 \pm 0.3 \mu \mathrm{g} \mathrm{l^{-1 }}$. P concentrations in unexchanged ballast tanks varied according to the source location, with tank water sourced wholly or partially from Geelong containing high levels of $\mathrm{P}\left(>40 \mu \mathrm{g} \mathrm{l}^{-1}\right)$, compared to tanks sourced in Adelaide or Townsville (13 to $19 \mu \mathrm{g} \mathrm{l}^{-1}$ ). In tanks exchanged in mid-ocean, $\mathrm{P}$ concentrations varied widely between 10 to $25 \mu \mathrm{g} \mathrm{l^{-1 }}$, thus, overlapping with concentrations in unexchanged tanks ballasted in Adelaide and Townsville.

The overall effect of BWE varied by cruise and among the 3 trace elements, with the greatest percent change in mean whole-tank concentrations being demonstrated by $\mathrm{Mn}$ (range 73 to $96 \%, \chi=86 \%$ ). For $\mathrm{Ba}$, concentrations in ballast tanks following BWE were not significantly different from concentrations in the ambient ocean in the region of BWE, whereas for $\mathrm{Mn}$ and $\mathrm{P}$, tank concentrations were generally elevated in exchanged ballast tanks relative to the ambient ocean (Fig. 3).

\section{Exchange efficiency}

BWE exchange efficiencies calculated from Eq. (1) varied by ballast tank and across different tracers. As would be expected from highly correlated measurements, C2* and $\mathrm{C} 3{ }^{*}$ produced consistent determinations of efficiency, with efficiencies for individual ballast tanks ranging from 92 to $98 \%$ by the ER method and 89 to $97 \%$ by the FT method (Table 3). Efficiencies calculated from $\mathrm{Ba}$ concentrations were usually slightly greater than, but typically within $5 \%$ of, those based on CDOM. Nonconservative behaviour of Mn, and to a lesser extent $\mathrm{P}$, has been observed in previous

Table 3. Efficiency of ballast water exchange (BWE) for individual tanks and tracers, assuming conservative mixing according to Eq. (1). C2* ${ }^{*} \mathrm{Ex} / \mathrm{Em}=320 / 414 \mathrm{~nm}, \mathrm{C} 3^{*}$ : Ex/Em = $370 / 494 \mathrm{~nm}$. See Table 1 for abbreviations

\begin{tabular}{|llccccc|}
\hline $\begin{array}{l}\text { Cruise. } \\
\text { Tank }\end{array}$ & BWE & C2 $^{*}$ & C3 $^{*}$ & Ba & Mn & P \\
\hline $1.2 \mathrm{p}$ & ER & 98 & 97 & 89 & 79 & 75 \\
$1.2 \mathrm{~s}$ & ER & 95 & 93 & 101 & 91 & 80 \\
$1.5 \mathrm{p}$ & $\mathrm{ER}$ & 97 & 96 & 100 & 86 & 76 \\
$1.5 \mathrm{~s}$ & $\mathrm{ER}$ & 98 & 97 & 95 & 82 & 73 \\
$2 . \mathrm{AP}$ & $\mathrm{FT}$ & 94 & 94 & 109 & 81 & -10 \\
$2 . \mathrm{FP}$ & $\mathrm{FT}$ & 90 & 91 & 84 & 89 & 60 \\
$3.5 \mathrm{p}$ & $\mathrm{ER}$ & 94 & 93 & 101 & 93 & 84 \\
$3.5 \mathrm{~s}$ & $\mathrm{ER}$ & 93 & 92 & 98 & 93 & 48 \\
$4.1 \mathrm{p}$ & $\mathrm{FT}$ & 90 & 89 & 101 & 109 & 85 \\
$4.1 \mathrm{~s}$ & $\mathrm{FT}$ & 92 & 92 & 93 & 109 & 83 \\
$4.5 \mathrm{p}$ & $\mathrm{FT}$ & 97 & 96 & 95 & 102 & -1 \\
$4.5 \mathrm{~s}$ & $\mathrm{FT}$ & 93 & 93 & 90 & 98 & 165 \\
\hline
\end{tabular}


studies (Murphy et al. 2008b) and may have influenced the results of the present study, with $\mathrm{Mn}$ and $\mathrm{P}$ exchange efficiencies typically being lower than those measured for CDOM and $\mathrm{Ba}$, and being highly variable overall and sometimes exceeding $100 \%$ (Table 3).

\section{Effect of proximity to land}

In Figs. 4 to 6, the concentrations of CDOM, Ba, Mn and $\mathrm{P}$ are plotted against distance from the Australian coastline, in order to assess how close to the Australian coast a ballast tank could be exchanged while potentially achieving an 'oceanic' tracer signature. Sites located $<100 \mathrm{nmi}$ from New Zealand are excluded from the figures.

\section{Dissolved organic matter fluorescence}

Surface ocean fluorescence of CDOM decreased with increasing distance from the Australian coastline. In Fig. 4, the concentration of CDOM (intensity at positions $\mathrm{C} 2{ }^{*}$ and $\mathrm{C} 3^{*}$ ) is plotted against distance from the Australian coastline, to illustrate the distance from land at which terrestrial influences can no longer be detected. Fluorescence intensity was highly variable among samples collected $<3 \mathrm{nmi}$ from shore due to differences in signal strength between terrestrial waters emanating from different ports and from the same ports during different seasons. The decline from relatively high nearshore levels proceeded rapidly, with background oceanic concentrations for $\mathrm{C} 2{ }^{*}$ and $\mathrm{C} 3$ * usually reached within $30 \mathrm{nmi}$ of shore. Uniformly low CDOM concentrations were reached at $~ 80 \mathrm{nmi}$ from land.

\section{Trace elements}

Surface ocean Ba concentrations decreased rapidly with distance from land on all cruises (Fig. 5). Within $3 \mathrm{nmi}$ of the Australian coast, Ba concentrations ranged from 4.5 to $35.0 \mu \mathrm{g} \mathrm{l}^{-1}$; however, by the time the vessels were $10 \mathrm{nmi}$ offshore, concentrations had decreased to $<7 \mu \mathrm{g} \mathrm{l}^{-1}$, and averaged $4.74 \pm 0.78 \mu \mathrm{g} \mathrm{l}^{-1}$ in samples collected $>50$ nmi from Australia or New Zealand. A small offshore seasonal shift was apparent, with Ba concentrations in the Tasman Sea in autumn (cruise NZ4) typically being $\sim 1 \mu g \mathrm{l}^{-1}$ lower than in other seasons.

Mn concentrations were also highest in port and coastal waters and decreased with distance from land (Fig. 5). Within $3 \mathrm{nmi}$ of the Australian coast, Mn concentrations ranged between 0.3 and $20 \mu \mathrm{g} \mathrm{l}^{-1}$, whereas

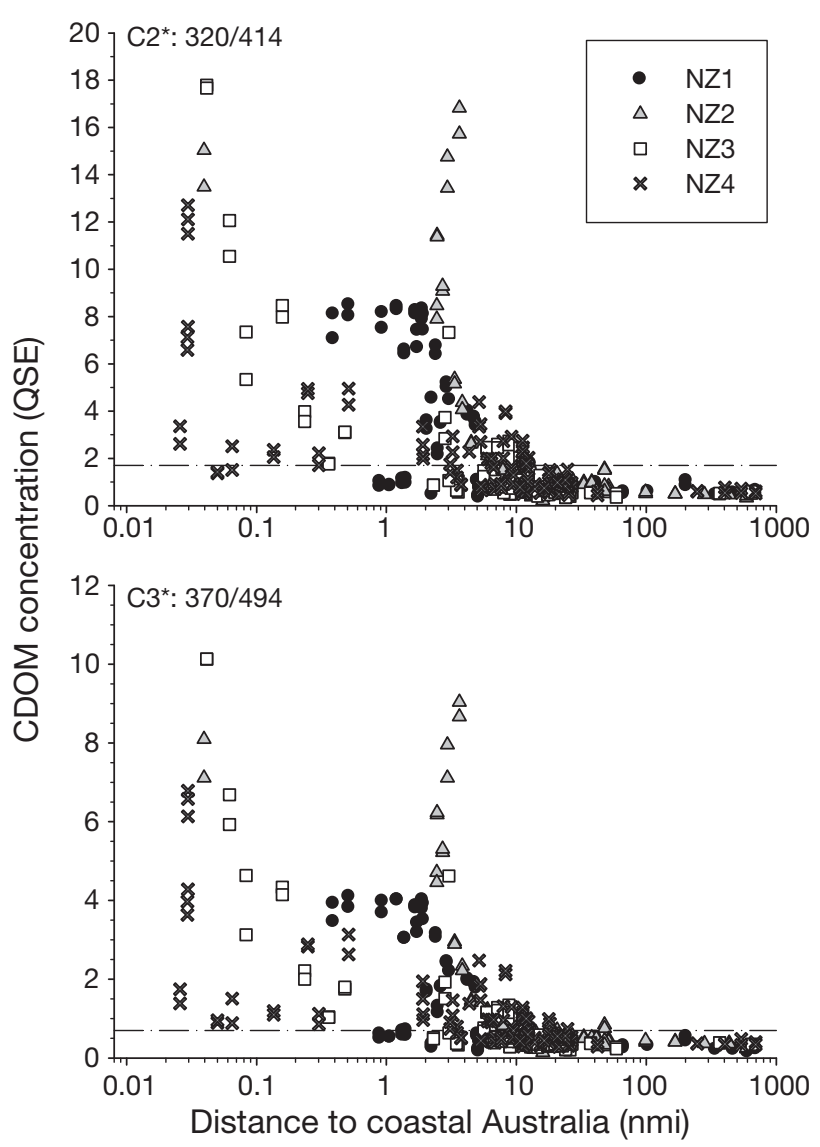

Fig. 4. Chromophoric dissolved organic matter (CDOM) concentrations (in quinine sulfate equivalents, QSE) at wavelengths C2* $(\mathrm{Ex} / \mathrm{Em}=320 / 414 \mathrm{~nm})$ and $\mathrm{C} 3{ }^{*}(\mathrm{Ex} / \mathrm{Em}=$ $370 / 494 \mathrm{~nm}$ ) in seawater samples from the Tasman Sea enroute to New Zealand. Data are means of duplicate samples; $(-\cdot-\cdot-)$ ballast water exchange (BWE) compliance thresholds for $\mathrm{C} 2{ }^{*}$ and $\mathrm{C} 3{ }^{*}$ (Murphy et al. 2006)

in samples collected >50 nmi offshore, average $\mathrm{Mn}$ concentrations were $0.51 \pm 0.31 \mu \mathrm{g} \mathrm{l}^{-1}$ and hence significantly lower than the lowest concentrations observed in unexchanged ballast tanks (Fig. 3). Oceanic Mn concentrations in summer (cruise NZ3) were $\sim 0.5 \mu \mathrm{g} \mathrm{l^{-1 }}$ higher than those measured during the other 3 cruises.

Total dissolved $\mathrm{P}$ concentrations in the offshore Tasman Sea (>50 nmi from Australia or New Zealand) averaged $12.16 \pm 2.98 \mu \mathrm{g} \mathrm{l}^{-1}$, increasing in an eastward direction from $\sim 7$ to $19 \mu \mathrm{g}^{-1}$ (Fig. 6). As a result of the higher $\mathrm{P}$ concentrations in the eastern Tasman, $\mathrm{P}$ in samples from the eastern Tasman Sea were indistinguishable from ranges in unexchanged ballast water from Townsville and Adelaide (Fig. 3). At the same time, maximum $\mathrm{P}$ concentrations in the Tasman Sea were less than half of $\mathrm{P}$ concentrations in unexchanged tanks containing ballast water originating partly or entirely from Geelong. 


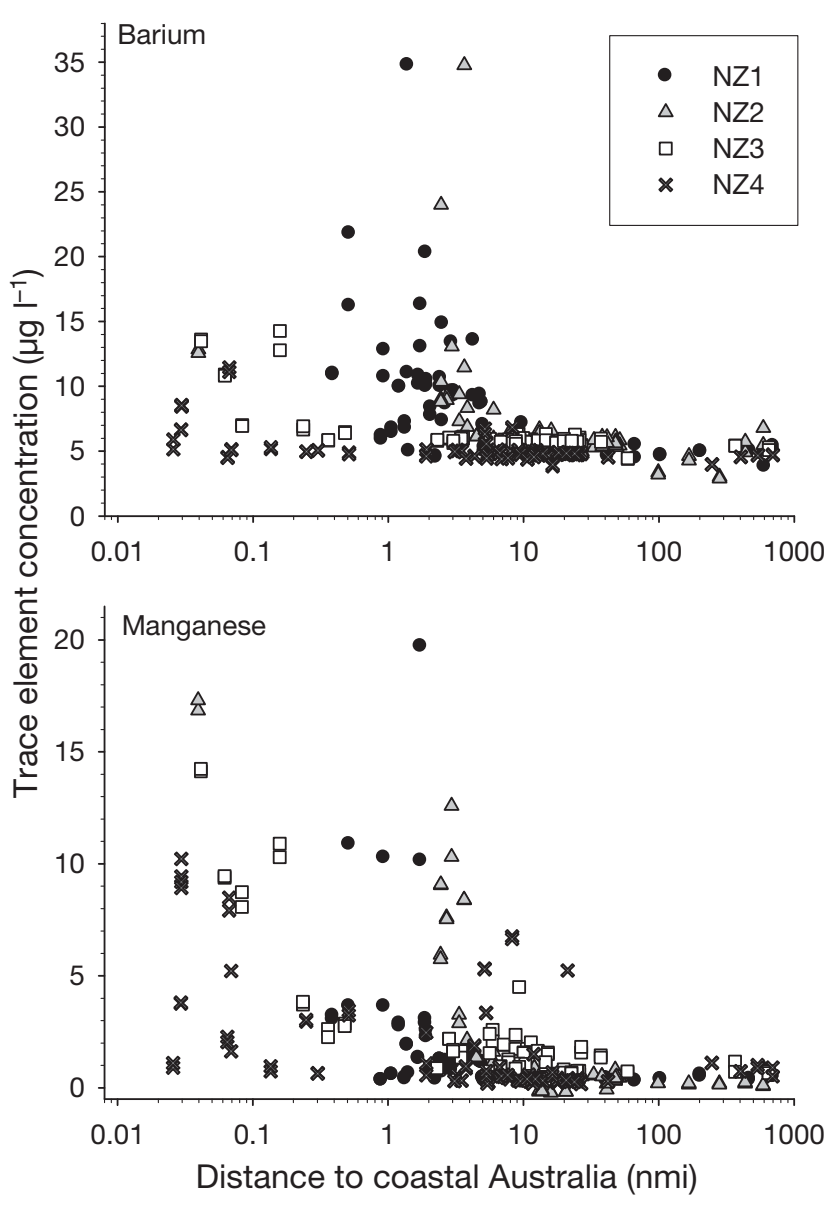

Fig. 5. Barium and manganese concentrations $\left(\mu g \mathrm{l}^{-1}\right.$ ) in seawater samples versus distance to the Australian coastline during seasonal cruises (NZ1 to 4) across the Tasman Sea enroute to New Zealand

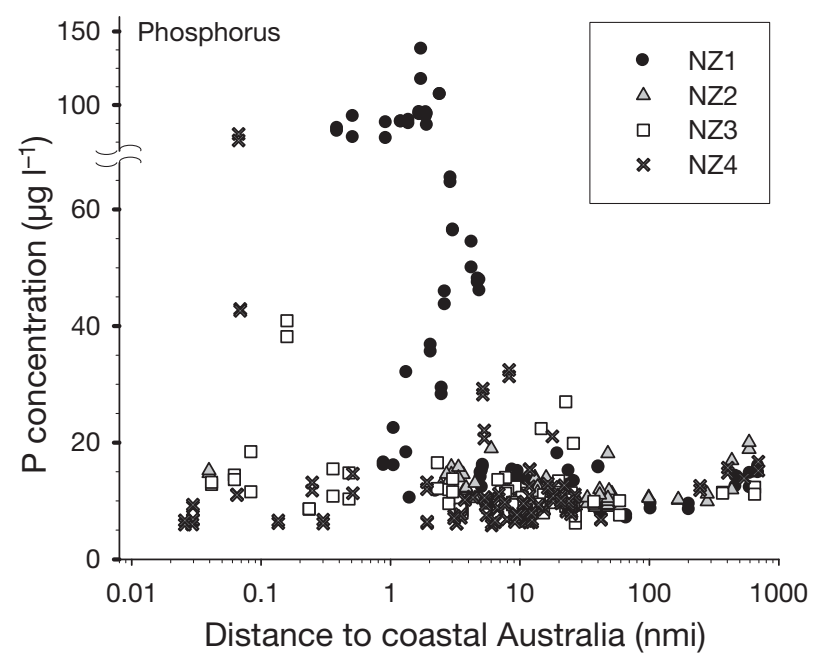

Fig. 6. Total dissolved phosphorus (P) concentrations $\left(\mu \mathrm{g} \mathrm{l}^{-1}\right)$ in seawater samples versus distance to the Australian coastline during seasonal cruises (NZ1 to 4) across the Tasman Sea enroute to New Zealand

\section{Multivariate analysis}

The optimal PLS regression model used 3 latent factors (components) to predict distance to shore from the concentrations of $\mathrm{Ba}, \mathrm{Mn}, \mathrm{P}$, salinity, $\mathrm{C} 2{ }^{*}$ and $\mathrm{C} 3{ }^{*}$ (Table 4). Salinity, Mn, Ba and P had little influence on the model, as indicated by their low variable importance in projection (VIP < 0.82) and small (absolute) regression coefficients, whereas $\mathrm{C} 2{ }^{*}$ and $\mathrm{C} 3^{*}$ had the greatest influence (Table 5). The 3-component model explained much more of the variation in tracer concentrations ( $84 \%$ of the variation in $\mathrm{X}$ ) than in distance from shore $(11 \%$ of the variation in $\mathrm{Y})$, and consequently has poor predictive ability. Also, since the 3component model explains only an additional $3 \%$ of the variability in distance from shore compared to a regression on $\mathrm{C} 2{ }^{*}$ alone, this indicates that the prediction of distance from shore from tracer concentrations is not significantly improved using a multivariate approach.

\section{DISCUSSION}

The present study greatly expands upon previous research in the North Pacific and Atlantic oceans, indicating that certain naturally occurring chemical tracers can be used to deduce the coastal versus oceanic origin of high-salinity ship ballast water. Overall, there was strong concordance between the southern and northern hemispheres in the application of chemical tracers for BWE verification over a wide geographic and seasonal range.

\section{Ballast water tracers in the ocean}

The concentrations of $\mathrm{Ba}$ and $\mathrm{Mn}$ in the present study were geographically and seasonally variable in nearshore waters, but quite stable in the Tasman Sea, averaging $4.78 \pm 0.78$ and $0.51 \pm 0.31 \mu \mathrm{g} \mathrm{l^{-1 }}$ respectively. In comparison, $\mathrm{P}$ concentrations were highly variable at the coast, while they increased $\sim 2$-fold from

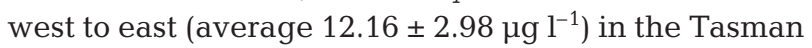
Sea. Comparable data on the distribution of these tracers in the same region are available in the published literature. Reported surface dissolved Ba of $\sim 6 \mu \mathrm{g} \mathrm{l^{-1 }}$ in the subtropical front south of Tasmania (Jacquet et al. 2004) is consistent with our measurements in the Tasman Sea. Mn measurements by Hatje et al. (2003) in Sydney's Port Jackson Estuary ranged between $~ 0.3$ and $25 \mu \mathrm{g} \mathrm{l}^{-1}$ in high-salinity (>30) surface seawater, and are consistent with the data collected in the present study. Also, Mn measurements by Sedwick et al. (1997) of 0.01 to $0.02 \mu \mathrm{g} \mathrm{l^{-1 }}$ at oceanic sites west of Tasmania are at the lower extent of our baseline Tasman 
Table 4. Proportion of variance explained by latent factors in partial least squares (PLS) regression of tracer concentrations vs. distance from shore.

Results for the optimal model with 3 latent factors are highlighted in bold

\begin{tabular}{|lcccc|}
\hline \multirow{2}{*}{$\begin{array}{l}\text { Latent } \\
\text { factors }\end{array}$} & $\begin{array}{c}\text { Tracer concentrations (X) } \\
\text { X-variance }\end{array}$ & $\begin{array}{c}\text { Cumulative X- } \\
\text { variance }\end{array}$ & Y-variance & $\begin{array}{c}\text { from shore (Y) } \\
\text { Cumulative Y- } \\
\text { variance }\end{array}$ \\
\hline 1 & 60.05 & 60.05 & 8.02 & 8.02 \\
2 & 12.53 & 72.58 & 2.58 & 10.60 \\
$\mathbf{3}$ & $\mathbf{9 . 6 6}$ & $\mathbf{8 2 . 2 4}$ & $\mathbf{0 . 5 3}$ & $\mathbf{1 1 . 1 3}$ \\
4 & 16.56 & 98.81 & 0.03 & 11.16 \\
\hline
\end{tabular}

Table 5. Variable influence on projection (VIP) and regression coefficients for 1-4 component partial least squares (PLS) models. Results for the optimal model with 3 latent factors are highlighted in bold. C2*: Ex/Em $=320 / 414 \mathrm{~nm}$, $\mathrm{C} 3^{*}: \mathrm{Ex} / \mathrm{Em}=370 / 494 \mathrm{~nm}$

\begin{tabular}{|c|c|c|c|c|c|c|c|c|}
\hline & \multicolumn{8}{|c|}{ Number of latent factors in model } \\
\hline & \multirow[b]{2}{*}{1} & \multicolumn{2}{|c|}{ VIP score- } & \multirow{2}{*}{4} & \multirow{2}{*}{$\overline{1}$} & \multirow{2}{*}{$\begin{array}{c}\text { gressio } \\
2\end{array}$} & \multirow{2}{*}{$\begin{array}{c}\text { coeffic } \\
\mathbf{3}\end{array}$} & \multirow{2}{*}{ ent } \\
\hline & & 2 & 3 & & & & & \\
\hline $\mathrm{Ba}$ & 0.95 & 0.76 & 0.75 & 0.75 & -0.06 & -0.04 & -0.06 & -0.07 \\
\hline $\mathrm{P}$ & 0.60 & 0.70 & 0.81 & 0.81 & -0.05 & 0.04 & 0.13 & 0.13 \\
\hline $\mathrm{Mn}$ & 0.07 & 0.68 & 0.67 & 0.67 & -0.02 & 0.13 & 0.11 & 0.11 \\
\hline Salinity & 0.04 & 0.03 & 0.03 & 0.05 & -0.01 & -0.02 & -0.01 & 0.01 \\
\hline $\mathrm{C} 2{ }^{*}$ & 2.19 & 1.93 & 1.89 & 1.88 & -0.09 & -0.18 & -0.21 & -0.21 \\
\hline $\mathrm{C} 3^{*}$ & 2.14 & 1.89 & 1.85 & 1.84 & -0.09 & -0.18 & -0.20 & -0.20 \\
\hline
\end{tabular}

under such definitions. The distance at which ambient ocean tracer concentrations were reached in the present study ranged from a few to $\sim 50 \mathrm{nmi}$ from port, with oceanic Ba concentrations generally established within $10 \mathrm{nmi}$ of land and oceanic CDOM levels 30 to $80 \mathrm{nmi}$ offshore. However, in close proximity to land $\quad<10$ to $50 \mathrm{nmi})$, seawater tracer concentrations could not accurately predict distance from land, even when salinity, $\mathrm{Ba}, \mathrm{P}, \mathrm{Mn}, \mathrm{C} 2{ }^{*}$ and $\mathrm{C} 3{ }^{*}$ were considered together in a multivariate analysis.

Overall, this indicates that it is likely to be very difficult to routinely detect BWE when ships perform BWE just a few miles from land, instead of at a legally specified distance from the coast. However, this limitation does not preclude the use of chemical tracers for identifying high-risk ballast water, for 2 reasons. (1) Statistical models indicate that larval invertebrate densities decrease rapidly with distance outside of enclosed embayments (Kinlan \& Gaines 2003, Siegel et

Sea concentrations. Our total dissolved phosphorus measurements in Port Phillip Bay and Bass Strait overlap with the measurements of Smith \& Longmore (1980) and our oceanic measurements of phosphate in the World Ocean Database, which also shows an east-west gradient in the Tasman Sea of $\sim 0.6$ to $0.26 \mu \mathrm{mol} \mathrm{l}^{-1}$ (Garcia et al. 2006).

Background CDOM fluorescence in the Tasman Sea $>50 \mathrm{nmi}$ from Australia and New Zealand during seasonal cruises in 2005-2006 was $0.56 \pm 0.13$ and $0.34 \pm$ 0.09 QSE at wavelength pairs $\mathrm{C} 2{ }^{*}$ and $\mathrm{C} 3{ }^{*}$ respectively (Fig. 4). We are unaware of any published CDOM fluorescence data from Australian coastal or offshore waters that can be directly compared with the present study; however, CDOM data in exchanged ballast tanks in the present study are of similar magnitude to data from tanks exchanged in the North Pacific (Murphy et al. 2006; Fig. 5).

BWE legislation around the world requires that ships conduct BWE in the mid-ocean at a specified minimum distance from the nearest coastline, typically 12 (AQIS 2007), 50 (CSLC 2006), or $200 \mathrm{nmi}$ (USCG 2004) or otherwise in 'deeper waters free from coastal influences' (MAF 2005). An understanding of the signal decay profile of ballast water tracers as a function of distance from land is needed in order to allow assessment of whether BWE was conducted in 'oceanic' locations al. 2003, Dunstan \& Bax 2007). Thus, ships conducting BWE even a few miles from port would be expected to encounter very low abundances of organisms originating within the port; furthermore, any larvae released during BWE would be quickly dispersed by prevailing currents and are unlikely to reach the coast at densities necessary to establish viable populations. (2) Geographic and seasonal variability in the offshore penetration of terrestrial tracer signals introduces a level of uncertainty that works in favor of regulators, since vessels that conduct BWE nearshore risk ballasting in an area that is subject to seasonally or regionally high tracer levels.

The designation of BWE zones in terms of 'safe' distances from shore has its basis in political boundaries ahead of ecological considerations. Although ships and regulators would benefit from the use of a single and unambiguous definition of acceptable BWE distances from shore, this is often not possible. Reasons include the sometimes short distances between neighboring ports or countries, and local topographic and oceanographic conditions affecting the distribution of coastal species. In a modeling study of Port Phillip Bay, Dunstan \& Bax (2008) predicted that BWE would be equally effective at reducing the risk of spreading an introduced seastar whether it was conducted near or far from shore. To verify BWE using chemical tracers, 
however, BWE must take place far enough from shore such that coastal signals are sufficiently diluted.

\section{Chemical tracers in ballast tanks}

Several chemical tracers, including total dissolved $\mathrm{Ba}, \mathrm{Mn}$ and CDOM, independently discriminated between ballast water exchanged in the Tasman Sea and unexchanged ballast water sourced from Adelaide, Geelong, Townsville and Botany Bay in Australia. In each case, significantly higher tracer concentrations occurred in unexchanged ballast tanks prior to BWE than in the same tanks following BWE, even when there was little accompanying change in salinity. This result confirms earlier research in the northern hemisphere, suggesting that all 3 tracers are more sensitive indicators of ballast water originating from highsalinity ports than is salinity (Murphy et al. 2004, 2006, $2008 b)$. At the same time, phosphorus concentration was not a reliable tracer of coastal ballast water except when the water was sourced from Geelong in Port Phillip Bay, although $\mathrm{P}$ has proved to be a sensitive indicator in other parts of the world (Murphy et al. $2008 b)$. This result is consistent with the known distribution of $\mathrm{P}$ in Australian coastal waters, which is characterized by (1) high concentrations year-round in Port Phillip Bay (Harris et al. 1996), and (2) low concentrations in nearshore coastal waters, increasing in southern latitudes together with elevated concentrations in the eastern Tasman Sea that are associated with a prominent tongue of high-P water intruding from the south (Garcia et al. 2006).

CDOM fluorescence intensity was the most sensitive and reliable tracer of ballast water origin in the present study, as was indicated by (1) greater relative changes in concentration following BWE than changes in salinity and in the concentrations of the trace elements; and (2) further offshore penetration of coastal waters than for the other tracers, with terrestrial influences being evident in some seawater samples collected >50 nmi from shore. This result is consistent with coastal CDOM distributions in the North Pacific (Murphy et al. 2006, 2008a, Boehme et al. 2008). Assuming that a ship loads ballast in an Australian port and then exchanges it in compliance with the law (i.e. with at least 95\% efficiency outside of coastal waters, MAF 2005) prior to arrival in New Zealand, then the vast majority of tanks ballasted in a port where $\mathrm{C} 2{ }^{*}$ and $\mathrm{C} 3{ }^{*}$ levels were respectively $\leq 17.7$ and 4.4 QSE would pass a verification test based on the 'compliance thresholds' of Murphy et al. 2006 (1.7 and 0.7 QSE, measured at wavelength pairs $\mathrm{C} 2{ }^{*}$ and $\mathrm{C} 3{ }^{*}$ respectively).

Although CDOM concentrations measured in samples collected external to the ships were always below the threshold levels, the thresholds were slightly exceeded in several exchanged ballast tanks. Using the maximum CDOM levels (19.8 and 11.0 QSE for $\mathrm{C} 2{ }^{*}$ and $\mathrm{C} 3^{*}$ respectively) measured in unexchanged tanks in the present study, and assuming that oceanic concentrations are below 0.83 and 0.51 QSE (mean + 2SD), then compliance thresholds of at least 1.78 and 1.04 QSE for C2* and C3* would appear to be conservative thresholds for ships in this region. Whereas variability in the very low background CDOM concentrations in oceanic seawater is unlikely to have a large influence on CDOM concentrations in ballast tanks, tracer concentrations in ports and coastal environments are much more variable in space and time (Murphy et al. 2006, 2008c, the present study). Thus surveys are warranted in Australia and overseas to ascertain whether there are ports with high invasion risk but low tracer concentrations, from which ships could import unexchanged ballast water that remain undetected. Recently, seasonal and spatial tracer surveys have been undertaken in 3 key Australian port systems, 4 ports in Asia and 4 ports on the west coast of North America, with further surveys being in the planning stages. These will assist in establishing robust compliance thresholds for BWE verification of ships arriving in New Zealand and elsewhere.

Barium and manganese were also sensitive indicators of ballast water source in ships carrying ballast water from ports in southeastern Australia. Previously, thresholds of $\sim 7$ to $8 \mu \mathrm{g} \mathrm{l^{-1 }}$ for $\mathrm{Ba}$, and 1 to $3 \mu \mathrm{g} \mathrm{l^{-1 }}$ for Mn were found to differentiate exchanged and unexchanged ballast tanks sourced from the North Atlantic and Pacific Oceans (Murphy et al. 2008b). In the present study, Ba and Mn concentrations were above 8.2 and $5.7 \mathrm{Mg} \mathrm{l}^{-1}$ respectively in unexchanged ballast tanks, and below 5.6 and $3.5 \mu \mathrm{g}^{-1}$ in tanks that had been exchanged in mid-ocean. This suggests that it is possible to establish $\mathrm{Ba}$ and $\mathrm{Mn}$ thresholds that are suitable for diagnosing coastal ballast water from Australia. Given the maximum Ba concentration (15.5 $\mu \mathrm{g}$ $\mathrm{l}^{-1}$ ) measured during this study and oceanic concentrations $<6.3 \mu \mathrm{g} \mathrm{l}^{-1}$ (mean $+2 \mathrm{SD}$ ), and assuming conservative mixing, a ballast tank containing a 5\%/95\% mixture of oceanic/coastal ballast water should have a Ba concentration not exceeding $6.8 \mu \mathrm{g} \mathrm{l}^{-1}$. In the present study, Ba concentrations in exchanged ballast tanks were always below this threshold. Similarly, assuming conservative mixing of high-salinity coastal (maximum $\left.31 \mu \mathrm{g} \mathrm{l}^{-1}\right)$ and oceanic Mn $\left(<1.1 \mu \mathrm{g} \mathrm{l}^{-1}\right)$ during BWE, Mn concentrations in exchanged ballast tanks should be $<2.6 \mu \mathrm{g} \mathrm{l}^{-1}$. Mn concentrations in some exchanged tanks significantly exceeded this threshold, which may be attributed to several factors, including < $<5 \%$ exchange efficiencies in some ballast tanks, measurement uncertainty, and potential nonconservative mix- 
ing behavior of this element (VanCappellen \& Wang 1996).

BWE efficiencies calculated for the tanks examined varied according to the tracer under consideration. Efficiencies that utilized CDOM and Ba data typically differed by $5 \%$ or less, whereas efficiencies based on Mn or P were often considerably different (Table 3). Factors responsible for this result include (1) sampling/analytical error, which is propagated from multiple sources when calculating exchange efficiencies according to Eq. (1) and is particularly problematic when concentration differences in the numerator or denominator are small, (2) relatively small oceanic sample sizes that affect the accuracy of oceanic baselines, partly due to contamination issues as discussed below, and (3) nonconservative behavior of tracers during BWE, due to reactive chemical behavior and/or possible release from resuspended sediments during BWE. Whereas the first 2 factors would affect all tracers to some degree, the last factor is probably most important for Mn and P (VanCappellen \& Wang 1996, Pan et al. 2002, Murphy et al. 2008b). For P, another factor that probably reduced the accuracy of BWE efficiency determinations was the added difficulty in establishing accurate oceanic baselines that was imparted by its east-west concentration gradient in the Tasman Sea.

Due to its high measurement precision, low variability in the open ocean, and conservative behavior in ballast tanks, CDOM fluorescence intensity appears to provide the most accurate tracer of BWE efficiency. Based on our CDOM measurements, approximately one-third of ballast tanks in the present study were exchanged with efficiencies lower than the $95 \%$ level specified by law. Relatively poor BWE efficiencies have also been observed in previous experiments (Murphy et al. 2004, 2008b) and are attributed to several factors, including engineering constraints, complicated physics, and human error (Hall \& Wilson 2006, Wilson et al. 2006). In the case of the MV 'Ciclope', the cooling water intake pipe from which shipside samples were taken was situated very near the ballast water outflow pipe, resulting in CDOM and trace element samples collected during BWE clearly being contaminated with ballast water outflow at several oceanic sites. This reduced the sample size and geographic extent of reliable open ocean data obtained during the present study, and might have also decreased flowthrough exchange efficiencies on the MV 'Ciclope' if there was contamination of intake water during BWE with outflow from the same tank. We neither encountered any cross-contamination of inflow and outflow seawater during BWE experiments on the MV 'General Villa', nor has this been observed in any previous studies (Murphy et al. 2006, 2008b). It is likely that sub- tle variations in ship design as observed here could play a significant role in determining the efficacy of BWE.

\section{Implementation of BWE verification}

From the point of view of regulators implementing chemical tracer methods for verifying mid-ocean BWE, there are 2 potential adverse outcomes of ballast water testing that need to be minimized. The results of the present study suggest that for ships arriving in New Zealand from Australia, the most frequent adverse outcome may be a failure to detect if tanks were exchanged in Australian coastal waters outside of a port, which consequently elevates the risk of contamination with non-native coastal species. The opposite situation, in which a false-positive determination is triggered by tracer levels exceeding compliance thresholds even after oceanic BWE, would generally require that 2 or more of the following conditions are met: (1) tracer concentrations in the original port water are high; (2) tracer concentrations in the offshore ocean where BWE is legitimately conducted are above known oceanic levels; and (3) a significant (>5\%) proportion of coastal ballast water is retained during BWE.

The first 2 causes of failure can only be addressed through extensive sampling aimed at establishing accurate baselines for ports and oceanic regions where BWE may legitimately be conducted. In this regard, it is important to realize that terrestrial tracer concentrations are typically inversely correlated with salinity; consequently, analysis of CDOM or trace elements in ballast tanks is necessitated only if salinities lie within a range common to both ports and the open ocean. Limiting tests to high-salinity tanks in which this condition is fulfilled tends to limit the range of CDOM, Ba, $\mathrm{Mn}$ and $\mathrm{P}$ concentrations in ballast tanks to the lower end of their natural ranges in ports.

Inadequate BWE exchange efficiencies have been suggested in past studies including this one; however, there is little doubt that most ships could significantly improve BWE efficacies if they had access to better information or the ability to test their BWE procedures empirically (Hall \& Wilson 2006). This, together with improved ship design, would reduce the incidence of ships failing BWE verification tests after inadvertently conducting incomplete BWEs. The Marine Environmental Protection Committee of the International Maritime Organisation has released ship design guidelines directed at increasing the efficiency of mid-ocean BWE (IMO 2006), while the recent advent of ballast water treatment testing facilities (Wright 2007) may also increase opportunities for determining exchange efficiencies. 


\section{CONCLUSIONS}

Policies in New Zealand and abroad promote the immediate use of BWE as a readily available management tool for reducing the delivery of invasive species to ports. Intensive sampling of ship ballast water and the ocean between southeastern Australia and New Zealand indicated that CDOM, Ba and Mn readily distinguish port from oceanic seawater in ballast tanks. This result confirms earlier observations in the northern Pacific and Atlantic oceans, suggesting that these parameters may be robust global tracers of BWE. Based on seasonal data collected in the present study, unexchanged ballast tanks from many Australian ports could be diagnosed by CDOM fluorescence above 1.78 and 1.04 QSE at wavelengths $\mathrm{C} 2{ }^{*}$ and $\mathrm{C} 3{ }^{*}$ respectively, and total dissolved concentrations for $\mathrm{Ba}$ and Mn above 6.8 and $2.6 \mu \mathrm{g} \mathrm{l}^{-1}$ respectively. While the results were unambiguous for CDOM and $\mathrm{Ba}$, Mn concentrations in some ballast tanks exceeded expectations based on conservative mixing, suggesting that nonconservative behavior of this element may complicate the application of Mn thresholds for BWE verification. Adjustments of the thresholds for other tracers may also be appropriate as further data become available and tolerances for 2 undesirable outcomes (failing to detect noncomplying ballast water and incorrectly returning a determination of noncompliance) are identified by regulatory bodies.

Whereas verification of the replacement of port with oceanic seawater in ballast tanks due to BWE was easily accomplished in the present study using several chemical tracers, the use of chemical tracers in a realworld application could offer limited sensitivity for distinguishing coastal from oceanic ballast water if a significant proportion of the coastal ballast water was sourced from outside of a port or embayment. Elevated terrestrial CDOM signals were found to extend up to $80 \mathrm{nmi}$ from the Australian coast, giving CDOM the greatest sensitivity for discriminating sources of ballast water from Australia.

Acknowledgements. L. Jones and A. Bell of MAF Biosecurity New Zealand provided relevant statistics on shipping arrivals. We thank Jebsen's Orient Shipping Services, Blue Crest Shipping Co., and Ership S. A. International for hosting this research on their ships and gratefully acknowledge Captains L. Anamaria, J. Moreno, J. R. Barandiaran Laca, C. Lecias, Jr., and their crews. Sampling assistance was provided by A. Balsom, E. Collinetti, and T. Pascoe. We thank P. Field of the Rutgers Inorganic Analytical Laboratory, Rutgers, the State University of New Jersey, for trace element analyses and $\mathrm{M}$. Wells for assistance with CDOM analyses at the University of Maine. Funding for this project was provided by the NZ Ministry of Fisheries grant ZBS 2004-01 and the US Coast Guard.

\section{LITERATURE CITED}

AQIS (Australian Quarantine and Inspection Service) (2007) Australian ballast water management requirements. Version 3, June 1, 2007. www.daff.gov.au/aqis/avm/ vessels/ballast/requirements, accessed 30 Apr 2008

Baturin GN (2003) Phosphorus cycle in the ocean. Lithol Min Res 38:101-119

Biosecurity Act (1993) New Zealand. An Act to restate and reform the law relating to the exclusion, eradication, and effective management of pests and unwanted organisms. GP Print, Wellington, RS, Vol 38, p 139

Blough NV, Del Vecchio R (2002) Chromophoric DOM in the coastal environment. In: Hansell DA, Carlson CA (eds) Biogeochemistry of marine dissolved organic matter. Academic Press, San Diego, CA, p 509-546

Blough NV, Zafiriou OC, Bonilla J (1993) Optical absorption spectra of waters from the Orinoco River outflow - terrestrial input of colored organic matter to the Caribbean. J Geophys Res C 98:2271-2278 doi:10.1029/92JC02763

Boehme J, Murphy K, Noble M, Brown C, Sparks D, Smith G, Ruiz G (2008) Full-scale study: demonstration project for the full-scale, ship-based application of a ballast water verification method to vessel arrivals on the U.S. Pacific coast. Final Report submitted to the National Sea Grant Program, Smithsonian Environmental Research Center, Edgewater, MD

Bruland KW, Franks RP (1983) Mn, Ni, Cu, Zn and Cd in the western North Atlantic. In: Wong CS, Boyle EA, Bruland KW, Burton JD, Goldberg ED (eds) Trace metals in seawater. Plenum Press, New York, p 395-414

Cariton JT, Geller JB (1993) Ecological roulette: the global transport of nonindigenous marine organisms. Science 261:78-82

Chen RF, Zhang Y, Vlahos P, Rudnick SM (2002) The fluorescence of dissolved organic matter in the Mid-Atlantic Bight. Deep-Sea Res II 49:4439-4459

Coble PG, Mopper K, Schultz CS (1993) Fluorescence contouring analysis of DOC intercalibration experiment samples: a comparison of techniques. Mar Chem 41:173-178

Cohen A, Foster B (2000) The regulation of biological pollution: preventing exotic species invasions from ballast water discharged into California coastal waters. Gold Gate Univ Law Rev 30:787-883

CSLC (California State Lands Commission) (2006) Ballast water regulations for vessels arriving at California ports or places after departing from ports or places within the Pacific Coast region. Title 2, Div 3, Chap 1, Art 4.6

De Jong S (1993) SIMPLS - an alternative approach to partial least-squares regression. Chemom Intell Lab Syst 18: 251-263

> Dunstan PK, Bax NJ (2007) How far can marine species go? Influence of population biology and larval movement on future range limits. Mar Ecol Prog Ser 344:15-28

> Dunstan PK, Bax NJ (2008) Management of an invasive marine species: defining and testing the effectiveness of ballast-water management options using management strategy evaluation. ICES J Mar Sci 65:841-850

Field MP, LaVigne M, Murphy KR, Ruiz GM, Sherrell RM (2007) Direct determination of P, V, Mn, As, Mo, Ba and U in seawater by SF-ICP-MS. J Anal Atom Spectrom 22:1145-1151

> Firestone J, Corbett JJ (2005) Coastal and port environments: international legal and policy responses to reduce ballast water introductions of potentially invasive species. Ocean Dev Int Law 36:291-316

Froelich PN, Bender ML, Luedtke NA, Heath GR, DeVries T 
(1982) The marine phosphorus cycle. Am J Sci 282: 474-511

Garcia HE, Locarnini RA, Boyer TP, Antonov JI (eds) (2006) World Ocean Atlas 2005, Vol 4: nutrients (phosphate, nitrate, silicate). US Government Printing Office, Washington, DC

Hall SD, Wilson KF (2006) Ballast water flushing of multiple tanks on board sea-going bulk carriers. J Mar Environ Eng 8:309-318

Hanor JS, Chan LH (1977) Non-conservative behavior of barium during mixing of Mississippi River and Gulf of Mexico waters. Earth Planet Sci Lett 37:242-250

Harris G, Batley G, Fox D, Hall D and others (1996) Port Phillip Bay environmental study final report. CSIRO, Canberra

Hatje V, Apte SC, Hales LT, Birch GF (2003) Dissolved trace metal distributions in Port Jackson estuary (Sydney Harbour), Australia. Mar Pollut Bull 46:719-730

Hewitt CL, Campbell ML, Thresher RE, Martin RB and others (2004a) Introduced and cryptogenic species in Port Phillip Bay, Victoria, Australia. Mar Biol 144:183-202

Hewitt CL, Willing J, Bauckham A, Cassidy AM, Cox CMS, Jones L, Wotton DM (2004b) New Zealand marine biosecurity: delivering outcomes in a fluid environment. N Z J Mar Freshw Res 38:429-438

HSNO (Hazardous Substances and New Organisms Act) (1996) New Zealand. An Act to restate and reform the law relating to the management of hazardous substances and new organisms. GP Print, Wellington, 1996 No. 30

$>$ Hunt CD, Tanis D, Bruce E, Taylor M (2007) Optical signatures of seawater and potential use for verification of mid-ocean ballast water exchange. Mar Ecol Prog Ser 331:35-47

IMO (International Maritime Organisation) (2004) International convention for the control and management of ships' ballast water and sediments. BWM/CONF/36, 16 Feb 2004, London

IMO (International Maritime Organisation) (2006) Guidelines for ballast water exchange design and construction standards (G11). Resolution MEPC149(55), adopted 13 Oct 2006

Inglis GJ (2001) Criteria for selecting New Zealand ports and other points of entry that have a high risk of invasion by new exotic marine organisms. Research report for Ministry of Fisheries Research Project ZBS2000/04 Objectives 1 \& 2, NIWA Client Report, Wellington

Inglis G, Gust N, Fitridge I, Floerl O, Woods C, Hayden B, Fenwick G (2007) Baseline survey for non-indigenous marine species: Port of Bluff. Biosecurity New Zealand Tech Pap No. 2005/09. Ministry of Agriculture and Forestry, Wellington

Jacquet SHM, Dehairs F, Rintoul S (2004) A high resolution transect of dissolved barium in the Southern Ocean. Geophys Res Lett 31:L14301 doi:10.1029/2004GL020016

Kinlan BP, Gaines SD (2003) Propagule dispersal in marine and terrestrial environments: a community perspective. Ecology 84:2007-2020

Knowler D (2005) Reassessing the costs of biological invasion: Mnemiopsis leidyi in the Black sea. Ecol Econ 52:187-199

Lakowicz JR (1983) Principles of fluorescence spectroscopy. Plenum Press, New York

Longmore AR (2007) Port Phillip Bay environmental management plan: monitoring the state of bay nitrogen cycling (2005-2006). Report No. 19, Primary Industries Research Victoria, Queenscliffe

MAF (Ministry of Agriculture and Forestry) (2005) Import health standard for ships' ballast water from all countries.
Rule issued pursuant to Section 22 of the Biosecurity Act 1993 on 13 June 2005, Wellington

MAF (Ministry of Agriculture and Forestry) (2007) Managing and controlling the risk to the marine environment from ballast water discharges: New Zealand's response to the international convention for the control and management of ship's ballast water and sediments. MAF Biosecurity New Zealand Discussion Paper No. 2007/04

Miller AW, Ruiz GM, Lion K (2004) Status and trends of ballast water management in the United States. Second biennial report of the national ballast information clearinghouse (January 2002 to December 2003). Submitted to the US Coast Guard, Smithsonian Environmental Research Center, Edgewater, MD

Miller AW, Ruiz GM, Lion K (2008) Status and trends of ballast water management in the United States. Third biennial report of the national ballast information clearinghouse (January 2004 to December 2005). Submitted to the US Coast Guard, Smithsonian Environmental Research Center, Edgewater, MD

Minton MS, Verling E, Miller AW, Ruiz GM (2005) Reducing propagule supply and coastal invasions via ships: effects of emerging strategies. Front Ecol Environ 3:304-308

Mopper K, Schultz CA (1993) Fluorescence as a possible tool for studying the nature and water column distribution of DOC components. Mar Chem 41:229-238

Moran M, Sheldon WMJ, Zepp RG (2000) Carbon loss and optical property changes during long-term photochemical and biological degradation of estuarine dissolved organic matter. Limnol Oceanogr 45:1254-1264

Murphy K, Boehme J, Coble P, Cullen J and others (2004) Verification of mid-ocean ballast water exchange using naturally occurring coastal tracers. Mar Pollut Bull 48: 711-730

Murphy KR, Ruiz GM, Dunsmuir WTM, Waite TD (2006) Optimized parameters for fluorescence-based verification of ballast water exchange by ships. Environ Sci Technol 40:2357-2362

Murphy K, Boehme J, Brown C, Noble M, Smith G, Sparks D, Ruiz G (2008a) Ballast water exchange verification: testing application of chemical tracers on the U.S. Pacific coast. Final report submitted to the California State Lands Commission, Smithsonian Environmental Research Center, Edgewater, MD

> Murphy KR, Field MP, Waite TD, Ruiz GM (2008b) Trace elements in ships' ballast water as tracers of mid-ocean exchange. Sci Total Environ 393:11-26

> Murphy KR, Stedmon CA, Waite TD, Ruiz GM (2008c) Distinguishing between terrestrial and autochthonous organic matter sources in marine environments using fluorescence spectroscopy. Mar Chem 108:40-58

Pan G, Krom MD, Herut B (2002) Adsorption-desorption of phosphate on airborne dust and riverborne particulates in east Mediterranean seawater. Environ Sci Technol 36: 3519-3524

Patterson M, Cole A (1999) Assessing the value of New Zealand's biodiversity. School of Resource and Environmental Planning, Massey University

Pimentel D, Wilson C, McCullum C, Huang R and others (1997) Economic and environmental benefits of biodiversity. Bioscience 47:747-757

Pimentel D, Zuniga R, Morrison D (2005) Update on the environmental and economic costs associated with alien-invasive species in the United States. Ecol Econ 52:273-288

Santagata S, Gasinaite ZR, Verling E, Cordell JR and others (2008) Effect of osmotic shock as a management strategy to reduce transfers of nonindigenous species among low- 
salinity ports by ships. Aquat Invas 3:61-76

Shiller AM (1997) Manganese in surface waters of the Atlantic ocean. Geophys Res Lett 24: 1495-1498

Sedwick PN, Edwards PR, Mackey DJ, Griffiths FB, Parslow JS (1997) Iron and manganese in surface waters of the Australian subantarctic region. Deep-Sea Res I 44: 1239-1253

Shaw TJ, Moore WS, Kloepfer J, Sochaski MA (1998) The flux of barium to the coastal waters of the southeastern USA: the importance of submarine groundwater discharge. Geochim Cosmochim Acta 62:3047-3054

Siegel DA, Kinlan BP, Gaylord B, Gaines SD (2003) Lagrangian descriptions of marine larval dispersion. Mar Ecol Prog Ser 260:83-96

Smith JD, Longmore AR (1980) Phosphate distribution in Bass Strait and south-eastern Australian coastal waters. Aust J Mar Freshw Res 31:119-128

Statistics New Zealand (2002) Australia is New Zealand's most significant trading partner. www.stats.govt.nz, accessed 9 Mar 2009

Statistics New Zealand (2009) Fish monetary stock account: 1996-2008. www.stats.govt.nz/analytical-reports/fish-

Editorial responsibility: Otto Kinne,

Oldendorf/Luhe, Germany monetary-stock-account-1996-2008.htm, accessed 9 Mar 2009

Stokstad E (2007) Invasive species: feared quagga mussel turns up in western United States. Science 315:453

USCG (United States Coast Guard) (2004) Mandatory ballast water management program for U.S. waters: Final Rule, 33 CFR 151, Subpart D, p 44952-44961

VanCappellen P, Wang YF (1996) Cycling of iron and manganese in surface sediments: a general theory for the coupled transport and reaction of carbon, oxygen, nitrogen, sulfur, iron, and manganese. Am J Sci 296:197-243

Wells ML, Smith GJ, Bruland KW (2000) The distribution of colloidal and particulate bioactive metals in Narragansett Bay, RI. Mar Chem 71:143-163

Wilson W, Chang P, Verosto S, Atsavapranee P, Reid DF, Jenkins PT (2006) Computational and experimental analysis of ballast water exchange. Nav Eng J 118:25-36

Wright D (2007) Logistics of shipboard and dockside testing of ballast water treatment systems in the United States. In: Gherardi F (ed) Biological invaders in inland waters: profiles, distribution, and threats, Vol 2. Springer, Dordrecht, p 657-668

Submitted: June 23, 2008; Accepted: June 25, 2009

Proofs received from author(s): September 2, 2009 